\title{
SISTEM PERHITUNGAN DAN PELAPORAN PAJAK PENGHASILAN PASAL 21 PADA UNIVERSITAS XYZ
}

\author{
Imelda Agustina ${ }^{1}$, Fatmawati Isnaini ${ }^{2}$ \\ ${ }^{1}$ S1 Sistem Informasi, Universitas Teknokrat Indonesia \\ ${ }^{2}$ S1 Sistem Informasi, Universitas Teknokrat Indonesia \\ 1,2 Jl. ZA. Pagar Alam No.9 -11, Labuhan Ratu, Kec. Kedaton, Kota Bandar Lampung, Lampung 35132 \\ Email: ${ }^{1}$ imeldaimel@teknokrat.ac.id, ${ }^{2}$ fatmawatiisnaini@teknokrat.ac.id
}

\begin{abstract}
Tax is one of the main sectors of government revenue which has an important role in development. XYZ University in calculating employee income tax is still done conventionally, that is, it is calculated using a spreadsheet based on the salary, allowances and honorarium that the employee receives each month. The process of calculating employee income tax often experiences errors in its calculations because there are differences in rates from income tax calculations, it must be calculated manually and causes the financial department to enter employee data one by one every month. The results of the information system for calculating and reporting employee income tax at XYZ University will help the financial department report employee income tax because they do not have to calculate the amount of tax from their employee income every month, and the test results produce a value of $100 \%$ in accordance with the system functionality testing using blackbox testing. And the results of the recapitulation of the entire ISO 25010 test get the results of a value of $81.6 \%$ with the criteria that are good for the calculation information system and employee income tax reporting can help the finance department of XYZ University.
\end{abstract}

Keyword: ISO 25010, Taxes, Computing, Systems, Information.

\begin{abstract}
Abstrak
Pajak merupakan salah satu sektor utama penerimaan pemerintah yang mempunyai peranan penting dalam pembangunan. Universitas XYZ dalam melakukan perhitungan pajak penghasilan karyawan masih dilakukan secara konvensional yaitu dihitung menggunakan spreadsheet berdasarkan gaji, tunjangan, dan honor yang didapat oleh karyawan setiap bulannya. Kendala yang dihadapi oleh Bagian Keuangan yaitu setiap bulannya harus melakukan perhitungan dengan aplikasi spreadsheet secara berulang-ulang sehingga menyebabkan kerangkapan data pada proses pencatatan perhitungan. Selain itu membutuhkan waktu yang cukup lama yaitu sekitar 1-2 hari kerja untuk melakukan perhitungan pajak penghasilan karyawan. Proses perhitungan pajak penghasilan karyawan sering mengalami kesalahan dalam perhitungannya karena terdapat perbedaan tarif dari perhitungan pajak penghasilan maka harus dihitung secara manual dan menyebabkan bagian keuangan memasukan data karyawan satu persatu setiap bulannya. Hasil dari sistem informasi perhitungan dan pelaporan pajak penghasilan karyawan pada Universitas XYZ akan membantu bagian keuangan dalam melaporkan pajak penghasilan karyawan karena tidak harus menghitung jumlah pajak dari penghasilan karyawannya setiap bulan, serta hasil pengujian menghasilkan nilai $100 \%$ sesuai dengan pengujian fungsionalitas sistem menggunakan blackbox testing. Dan Hasil rekapitulasi dari keseluruhan pengujian ISO 25010 medapatkan hasilnya nilai sebesar 81,6\% dengan kriteria yaitu baik untuk sistem informasi perhitungan dan pelaporan pajak penghasilan karyawan dapat membantu bagian keuangan Universitas XYZ.
\end{abstract}

Kata Kunci: ISO 25010, Pajak, Perhitungan, Sistem, Informasi.

\section{Pendahuluan}

Pajak merupakan salah satu sektor utama penerimaan pemerintah yang mempunyai peranan penting dalam pembangunan. Sehingga dalam pelaksanaannya sektor perpajakan diatur melalui sistem beserta UndangUndang yang telah ditetapkan. Melalui sistem tersebut diharapkan pengadaan pembangunan nasional melalui sektor pajak dapat dimaksimalkan penggunaannya untuk kepentingan bersama. Pajak merupakan aspek yang penting dalam proses pembangunan suatu bangsa khususnya di Indonesia, karena pembangunan bertujuan untuk mewujudkan serta meningkatkan kesejahteraan suatu bangsa. Hal ini ditegaskan dalam Undang-Undang dasar 1945 pasal 23A.

Perusahaan perlu melakukan pencatatan agar dapat menghitung beban pajak yang harus dibayarkan dengan benar dalam melakukan pembayaran Pajak Penghasilan 
Pasal 21. Perhitungan pajak penghasilan merupakan perhitungan atas pajak penghasilan yang dimana formula perhitungannya telah diatur di dalam peraturan perpajakan yang berlaku saat ini. Setelah perhitungan pajak penghasilan dilakukan, maka perusahaan melakukan pemotongan pajak penghasilan. Pemotongan pajak penghasilan dilakukan sesuai perhitungan jumlah pajak yang harus dibayarkan atas penghasilan karyawan yang bekerja di perusahaan. Penyetoran pajak penghasilan dilakukan setiap akhir tahun pajak masa dan peraturan penyetoran juga terdapat dalam peraturan perpajakan. Penyetoran pajak dilakukan di bank atau di kantor pos, yang dimana akan diberikan bukti tanda pembayaran Pajak Pengahasilan Pasal 21. Setelah penyetoran pajak dilakukan, maka dilakukanlah pelaporan pajak yang merupakan pelaporan kepada Kantor Pelayanan Pajak tempat perusahaan tersebut terdaftar atas selesainya melakukan pembayaran Pajak Penghasilan Pasal 21 [1].

Undang-Undang Perpajakan saat ini yang telah mengalami tiga kali perubahan. Terakhir telah dilakukan perubahan atas Undang-Undang No.17 Tahun 2000 menjadi Undang-Undang No.36 Tahun 2008 tentang Pajak Penghasilan. Dengan Undang-Undang perpajakan yang terus mengalami perbaikan, penyesuaian, dan perubahan. Self assessment system yang telah diterapkan pemerintah memberikan kepercayaan kepada Wajib Pajak untuk menghitung, membayar, dan melaporkan sendiri besarnya pajak yang harus dibayar.

Universitas XYZ dalam melakukan perhitungan pajak penghasilan karyawan masih dilakukan secara konvensional yaitu dihitung menggunakan spreadsheet berdasarkan gaji, tunjangan, dan honor yang didapat oleh karyawan setiap bulannya. Kendala yang dihadapi oleh Bagian Keuangan yaitu setiap bulannya harus melakukan perhitungan dengan aplikasi spreadsheet secara berulangulang sehingga menyebabkan kerangkapan data pada proses pencatatan perhitungan. Selain itu membutuhkan waktu yang cukup lama yaitu sekitar 1-2 hari kerja untuk melakukan perhitungan pajak penghasilan karyawan. Proses perhitungan pajak penghasilan karyawan sering mengalami kesalahan dalam perhitungannya karena terdapat perbedaan tarif dari perhitungan pajak penghasilan maka harus dihitung secara manual dan menyebabkan bagian keuangan memasukan data karyawan satu persatu setiap bulannya. Penggunaan aplikasi perhitungan pengolahan pajak penghasilan menggunakan komputerisasi menjadi Lebih praktis dan waktu penggunaan relatif lebih singkat, Tingkat kekeliruan lebih rendah, hasil laporan sesuai dengan kebutuhan [2], [3], [4].

\section{Metode}

Kerangka penelitian merupakan gambaran besar penulis dalam melakukan penelitian [5], dapat dilihat pada gambar dibawah ini :

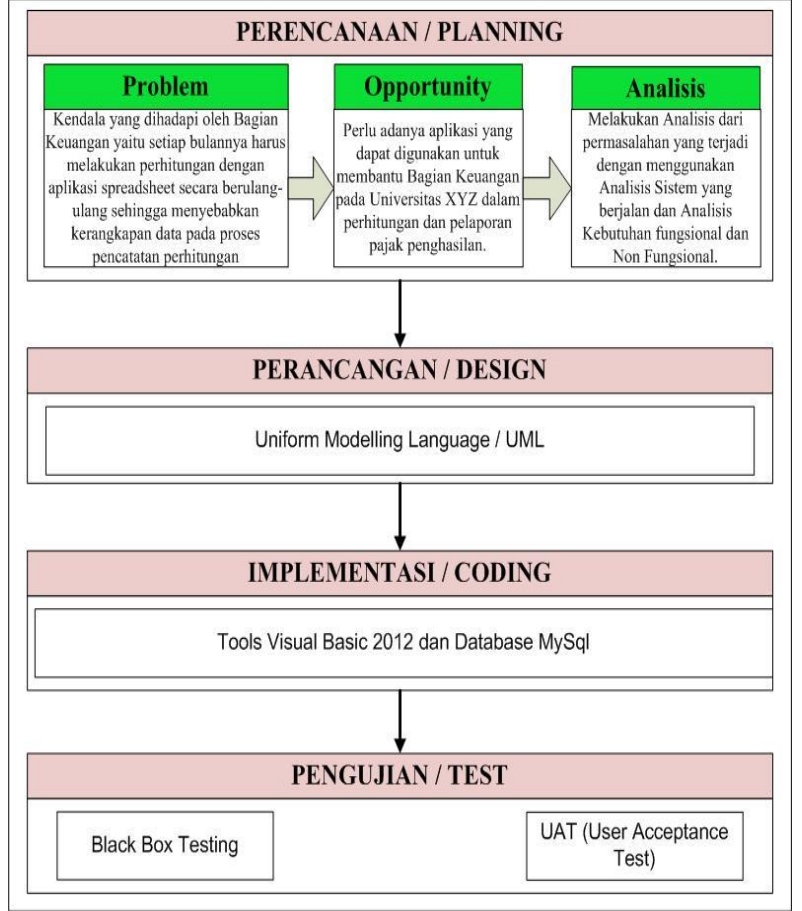

Gambar 1. Kerangka Penelitian

Tahapan penelitian merupakan kegiatan penelitian yang dilakukan secara terencana, teratur, dan sistematis untuk mencapai tujuan tertentu [6]. Tahapan penelitian ini juga merupakan pengembangan dari kerangka penelitian, dan terbagi lagi menjadi beberapa sub menu bagian. Penjelasan tahapan penelitian adalah

1. Perencanaan

Melakukan wawancara dengan bagian keuangan pada pihak Universitas XYZ untuk mendapatkan informasi tentang permasalahan yang terjadi dalam proses perhitungan pajak penghasilan karyawan pada Universitas XYZ. Selanjutnya dari wawancara yang telah dilakukan melakukan penentuan kesempatan / opportunity untuk mengatasi permasalahan yang terjadi. Serta melakukan analisis dari permasalahan yang terjadi.

2. Perancangan

Tahapan perancangan yaitu membuat sebuah rancangan sistem informasi dengan menggunakan permodelan berorientasi objek yaitu merancang Usecase Diagram, Activity Diagram, dan Class Diagram.

3. Implementasi

Tahapan implementasi yaitu membuat aplikasi berbasis desktop dengan bahasa pemrograman dan Database

4. Pengujian

Tahapan pengujian yaitu membuat pengujian terhadap aplikasi yang sudah dibuat dengan menggunakan Blackbox Testing untuk menguji fungsionalitas sistem.

5. Hasil

Dari empat tahapan penelitian yang dilakukan akan menghasilkan Sistem Informasi Perhitungan dan Pelaporan Pajak Penghasilan untuk Karyawan Tetap (Studi Kasus : Universitas XYZ).

\subsection{Usecase Diagram}


Usecase diagram sistem informasi perhitungan dan pelaporan pajak penghasilan karyawan pada Universitas XYZ adalah :

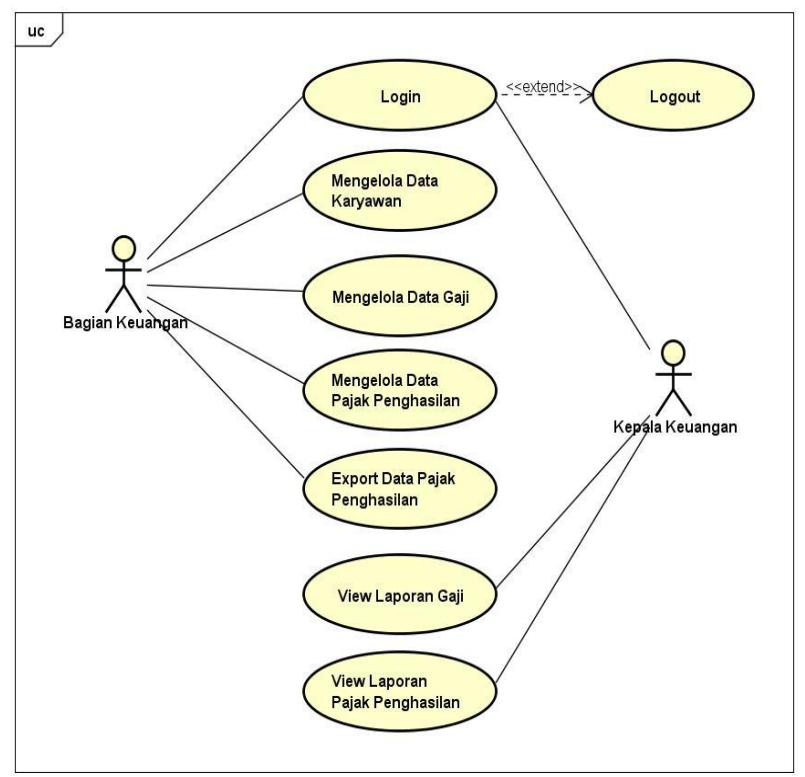

Gambar 2. Usecase Diagram

\subsection{Class Diagram}

Class diagram sistem informasi perhitungan dan pelaporan pajak penghasilan karyawan pada Universitas XYZ adalah :

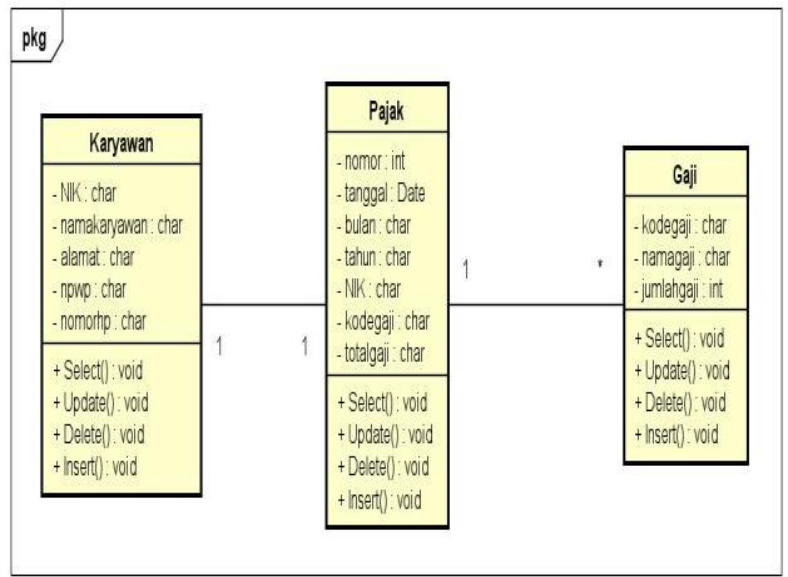

Gambar 3. Class Diagram

\section{Hasil dan Analisis}

Implementasi Sistem merupakan kumpulan dari elemenelemen yang telah didesain kedalam bentuk pemrograman untuk menghasilkan suatu tujuan yang dibuat berdasarkan kebutuhan. Implementasi sistem informasi perhitungan dan pelaporan pajak penghasilan karyawan pada Universitas XYZ dirancang untuk mempermudah pada saat perhitungan pajak pada Universitas XYZ [7], [8], [9]. Implementasi sistem informasi perhitungan dan pelaporan pajak penghasilan karyawan pada Universitas XYZ adalah sebagai berikut

\subsection{Implementasi Form Login}

Implementasi form login adalah tampilan pertama kali untuk mengakses aplikasi yang digunakan. Tampilan form login yaitu

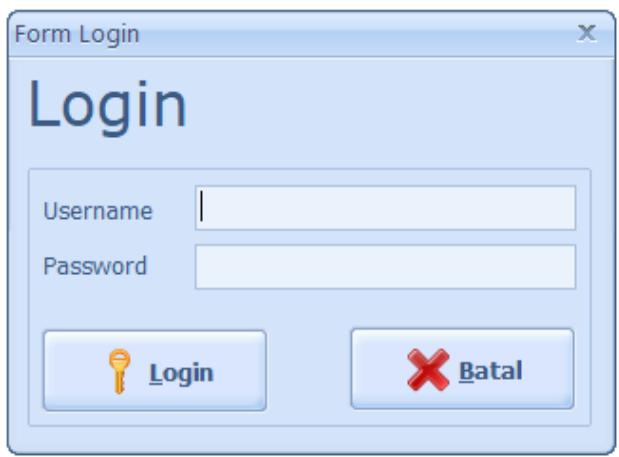

Gambar 4. Implementasi Form Login

\subsection{Implementasi Form Menu Utama}

Implementasi form login adalah tampilan pertama kali ketika berhasil melakukan login

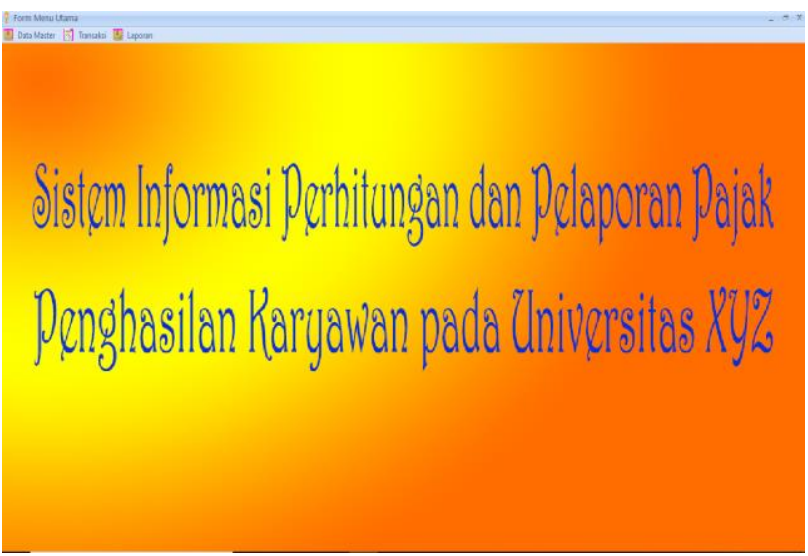

Gambar 5. Implementasi Form Login

\subsection{Implementasi Form Data Karyawan}

Implementasi form data karyawan adalah tampilan ketika memilih menu karyawan. Tampilan form data karyawan yaitu

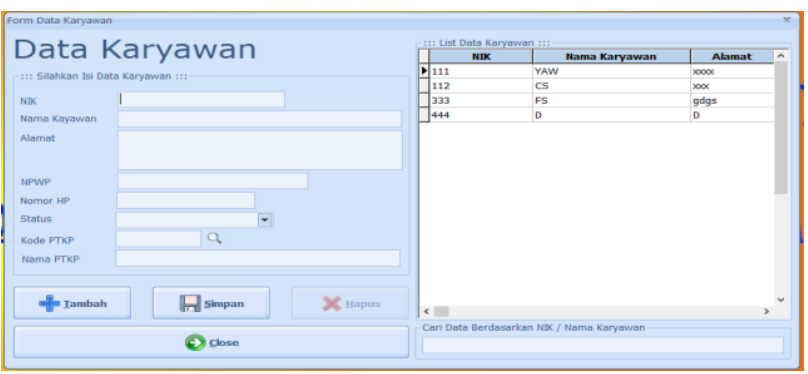

Gambar 6. Implementasi Form Login

\subsection{Implementasi Form Jenis Gaji}

Implementasi form jenis gaji adalah tampilan ketika memilih menu jenis gaji. Tampilan form jenis gaji yaitu 


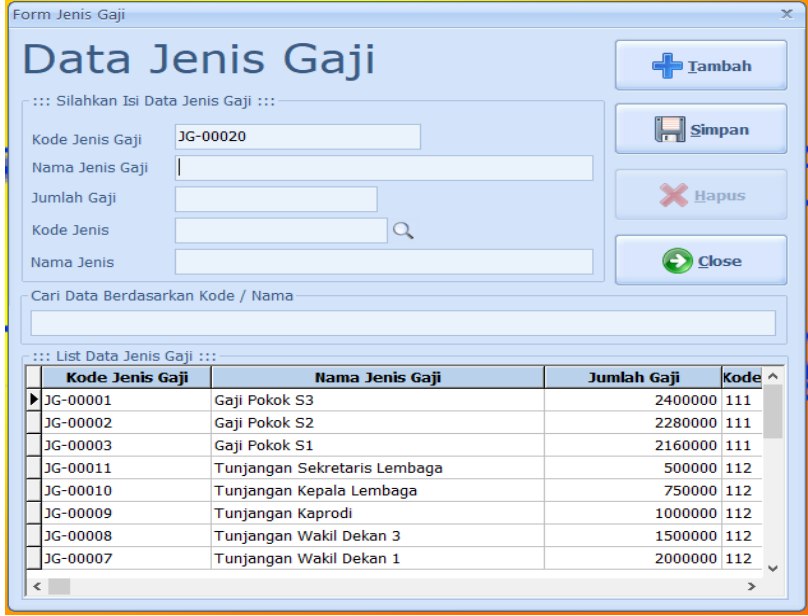

Gambar 7. Implementasi Form Jenis Gaji

\subsection{Implementasi Form Export}

Implementasi form export pajak adalah tampilan ketika memilih menu export pajak. Tampilan form export pajak yaitu

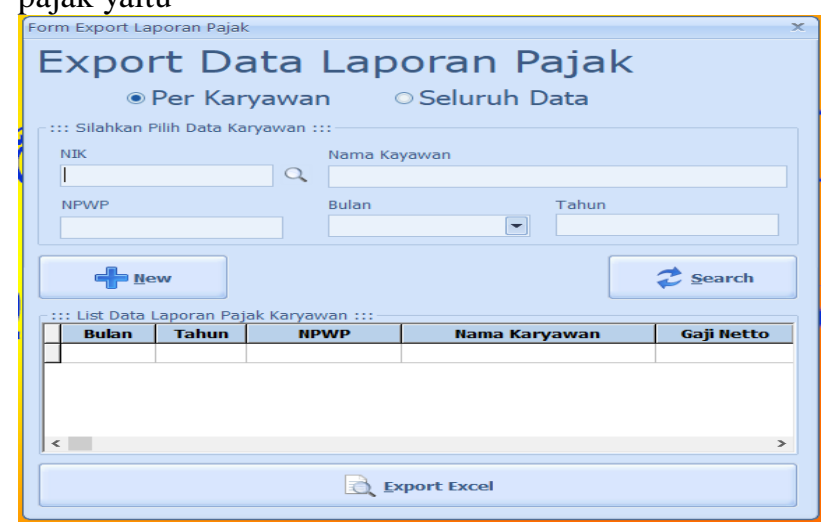

Gambar 8. Implementasi Form Export

\subsection{Implementasi Form PTKP}

Implementasi form PTKP adalah tampilan ketika memilih menu PTKP. Tampilan form PTKP yaitu

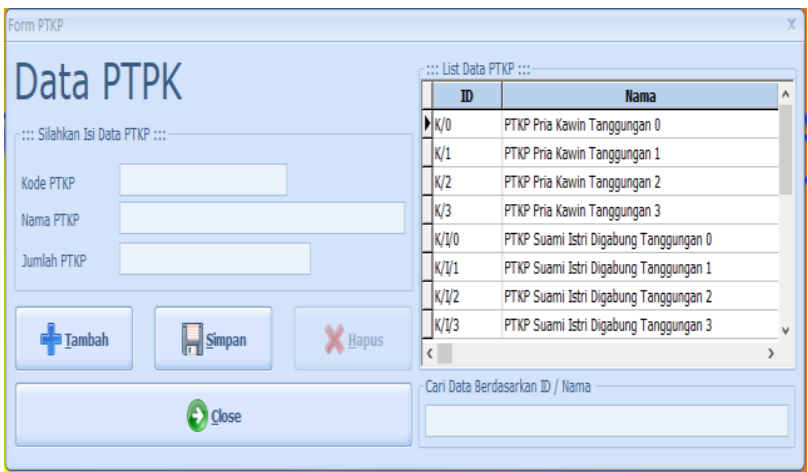

Gambar 9. Implementasi Form PTKP

\subsection{Implementasi Form Perhitungan Pajak}

Implementasi form perhitungan pajak adalah tampilan pengguna memilih menu perhitungan pajak. Tampilan form perhitungan pajak yaitu

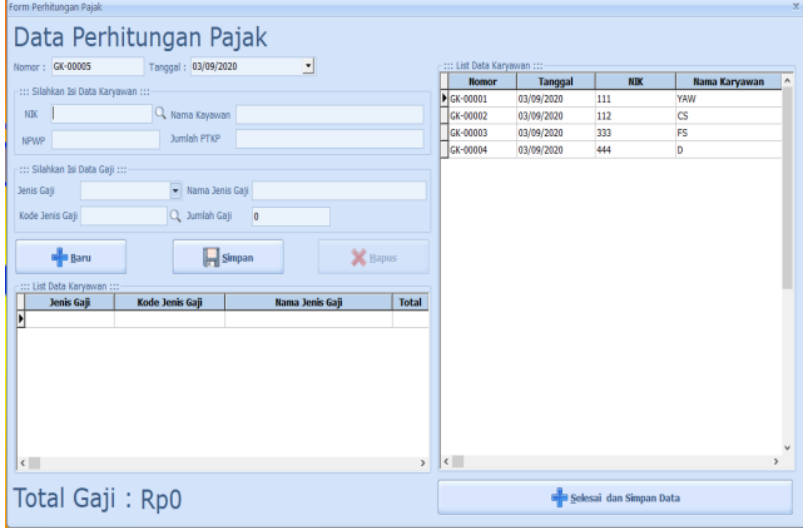

Gambar 10. Implementasi Form Perhitungan Pajak

\subsection{Implementasi Form Potongan BPJS}

Implementasi form potongan BPJS adalah tampilan ketika memilih menu potongan BPJS. Tampilan form potongan BPJS yaitu

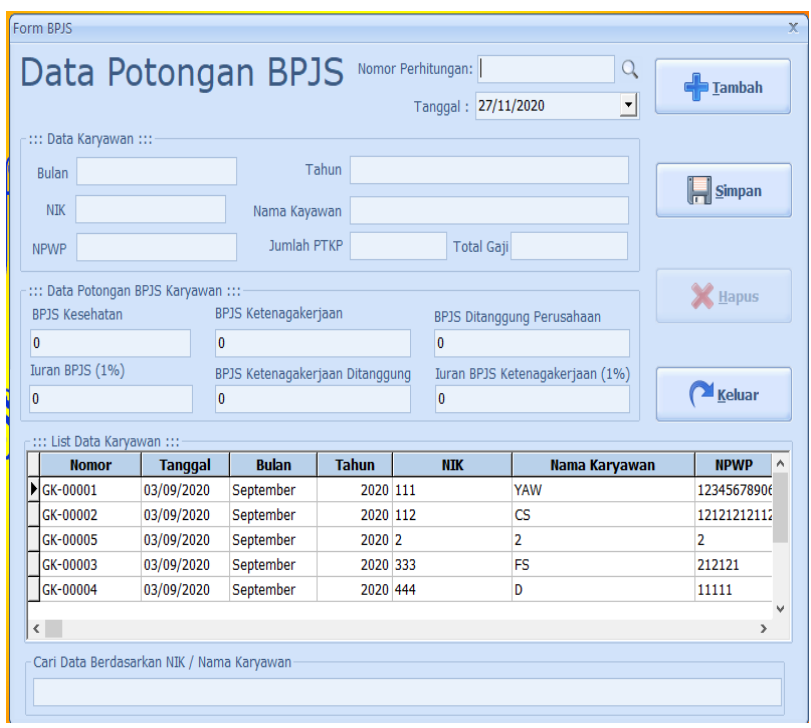

Gambar 11. Implementasi Form Potongan BPJS

\subsection{Implementasi Form Laporan}

Implementasi form cetak laporan pajak adalah tampilan ketika memilih menu cetak laporan. Tampilan form cetak laporan yaitu

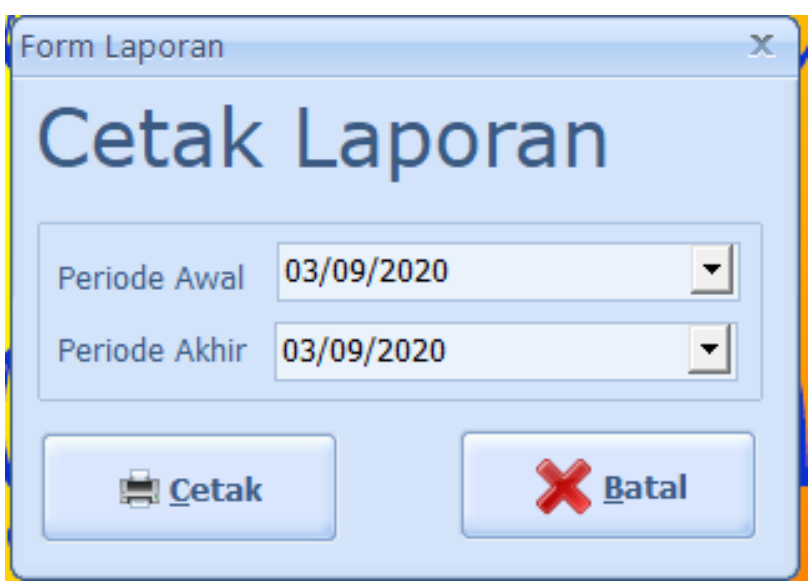

Gambar 12. Implementasi Form Cetak Laporan 


\subsection{Rekapitulasi Hasil Pengujian ISO 25010}

Berdasarkan hasil pengujian diperoleh dari kuisioner, hasil rekapitulasi pengujian berdasarkan 3 faktor ISO 25010.

Tabel 1. Hasil Kesimpulan Pengujian ISO 25010

\begin{tabular}{cccccc}
\hline $\begin{array}{l}\text { N } \\
\text { o }\end{array}$ & $\begin{array}{c}\text { Aspek / } \\
\text { Kriteria }\end{array}$ & $\begin{array}{c}\text { Skor } \\
\text { Aktual }\end{array}$ & $\begin{array}{c}\text { Skor } \\
\text { Ideal }\end{array}$ & $\begin{array}{c}\text { \% } \\
\text { Skor } \\
\text { Total }\end{array}$ & $\begin{array}{c}\text { Krite } \\
\text { ria }\end{array}$ \\
\hline 1 & $\begin{array}{l}\text { Functional } \\
\text { Suitability }\end{array}$ & 49 & 60 & 81,67 & Baik \\
\hline 2 & Reliability & 48 & 60 & 80 & Baik \\
\hline 3 & $\begin{array}{l}\text { Performance } \\
\text { efficiency }\end{array}$ & 99 & 120 & 82,5 & Baik \\
\hline & Total & $\mathbf{1 9 6}$ & $\mathbf{2 4 0}$ & $\mathbf{8 1 , 6}$ & Baik \\
\hline
\end{tabular}

Hasil rekapitulasi dari keseluruhan pengujian ISO 25010 medapatkan hasilnya nilai sebesar $81,6 \%$ dengan kriteria yaitu baik untuk sistem informasi perhitungan dan pelaporan pajak penghasilan karyawan dapat membantu bagian keuangan Universitas XYZ.

\subsection{Kesimpulan Hasil Pengujian Black Box Testing}

Hasil pengujian black box testing dari 6 komponen pengujian yang sudah dilakukan maka didapatkan hasil yaitu :

Tabel 2. Hasil Pengujian Black Box Testing

\begin{tabular}{lcc} 
Kriteria Pengujian & $\begin{array}{c}\text { Jumlah Jawaban } \\
\text { Sesuai }\end{array}$ & $\begin{array}{c}\text { Tidak } \\
\text { Sesuai }\end{array}$ \\
Form Login & 3 & 0 \\
\hline Form Data Karyawan & 4 & 0 \\
\hline Form Data Jenis & 4 & 0 \\
\hline Form Data Jenis Gaji & 4 & 0 \\
\hline Form Data Penggajian & 4 & 0 \\
\hline Form Laporan & 2 & 0 \\
\hline Total Jawaban & $\mathbf{2 1}$ & $\mathbf{0}$
\end{tabular}

Berdasarkan hasil rekapitulasi 6 kriteria pengujian yang telah dilakukan didapatkan hasil jumlah jawaban dari responden yaitu mempunyai nilai $100 \%$ sesuai dengan pengujian fungsionalitas sistem menggunakan blackbox testing.

\section{Kesimpulan}

Berdasarkan hasil uraian yang telah dipaparkan dapat diambil simpulan yaitu Sistem informasi perhitungan dan pelaporan pajak pajak penghasilan karyawan pada Universitas XYZ dirancang dengan menggunakan pendekatan berorientasi objek yaitu dengan menggunakan usecase diagram, class diagram, sehingga Pendekatan berorientasi objek merupakan solusi paradigma pemrograman yang berorientasikan kepada objek. Implementasi sistem informasi perhitungan dan pelaporan pajak pajak penghasilan karyawan pada Universitas XYZ menggunakan Bahasa pemrograman dan database MySql, sehingga pengolahan data perhitungan pajak menjadi lebih mudah dan secara otomatis tampil pada saat akan selesai melakukan input data penggajian, serta pelaporan pajak yang dihasilkan dari sistem ada fitur export dalam format Microsoft Excel sehingga bagian keuangan tidak harus menghitung laporan pajak yang akan dilaporkan. Hasil dari sistem informasi perhitungan dan pelaporan pajak penghasilan karyawan pada Universitas $\mathrm{XYZ}$ akan membantu bagian keuangan dalam melaporkan pajak penghasilan karyawan karena tidak harus menghitung jumlah pajak dari penghasilan karyawannya setiap bulan, serta hasil pengujian menghasilkan nilai $100 \%$ sesuai dengan pengujian fungsionalitas sistem menggunakan blackbox testing. Dan Hasil rekapitulasi dari keseluruhan pengujian ISO 25010 medapatkan hasilnya nilai sebesar $81,6 \%$ dengan kriteria yaitu baik untuk sistem informasi perhitungan dan pelaporan pajak penghasilan karyawan dapat membantu bagian keuangan Universitas XYZ.

\section{Daftar Pustaka}

[1] B. J. Kaleb, "Penerapan Sistem Informasi Manajemen Dan Pengawasannya Di Kantor Pelayanan Pajak Pratama Manado," J. EMBA J. Ris. Ekon. Manajemen, Bisnis dan Akunt., vol. 7, no. 1, pp. 781-790, 2019, doi: 10.35794/emba.v7i1.22555.

[2] D. Darwis, A. Ferico Octaviansyah, H. Sulistiani, and R. Putra, "Aplikasi Sistem Informasi Geografis Pencarian Puskesmas Di Kabupaten Lampung Timur," J. Komput. dan Inform., vol. 15, no. 1, pp. 159-170, 2020.

[3] Setiawansyah, H. Sulistiani, and D. Darwis, "Penerapan Metode Agile untuk Pengembangan Online Analytical Processing ( OLAP ) pada Data Penjualan ( Studi Kasus: CV Adilia Lestari )," J. CoreIT, vol. 6, no. 1, pp. 50-56, 2020.

[4] D. A. Megawaty, Setiawansyah, M. Bakri, and E. Damayanti, "SISTEM MONITORING KEGIATAN AKADEMIK SISWA," vol. 14, no. 2, pp. 98-101, 2020.

[5] Y. Adhawiyah, N. Kumaladewi, and M. Caturutami, "RANCANG BANGUN SISTEM INFORMASI PENILAIAN KINERJA PEGAWAI MENGGUNAKAN METODE PSYCOLOGICAL APPRAISAL (StudiKasus:Kantor Wilayah Kementerian Agama DKI Jakarta)," Stud. Inform. J. Sist. Inf., vol. 10, no. 2, pp. 119-126, 2017.

[6] R. Indra, A. Thyo, and A. Rahman, "Implementasi Metode Pengembangan Sistem Extreme Programming ( XP ) pada Aplikasi Investasi Peternakan Implementation of Extreme Programming ( XP ) System Development Method in Livestock Investment Aplication," vol. 8, no. 3, pp. 272-277, 2020, doi: 10.26418/justin.v8i3.40273.

[7] I. Tangkudung, R. D. R. Dako, and A. Y. Dako, "Evaluasi Website Menggunakan Metode Iso/Iec 25010," SemanTECH (Seminar Nas. Teknol. Sains dan Humaniora), vol. 1, no. 1, pp. 87-107, 2019, [Online]. Available: 
http://jurnal.poligon.ac.id/index.php/semantech/articl e/view/463.

[8] S. L. Saepudin and R. P. Dhaniawaty, "Sistem Informasi Penyewaan Mobil Berbasis Web padaPT. Frasindo Lima Mandiri," Jamika, vol. 9, no. 2, pp. 70 82, 2019, doi: 10.34010/jamika.v9i2.

[9] H. Sulistiani, R. Triana, and N. Neneng, "Sistem
Informasi Akuntansi Pengelolaan Piutang Usaha untuk Menyajikan Pernyataan Piutang (Open Item Statement) Pada PT Chandra Putra Globalindo," J. Tekno Kompak, vol. 12, no. 2, p. 34, 2018, doi: 10.33365/jtk.v12i2.97. 